\title{
Prevalence of chronic pain in Brazil: a descriptive study
}

\author{
Prevalência de dor crônica no Brasil: estudo descritivo
}

Fernando Holanda Vasconcelos ${ }^{1}$, Gessi Carvalho de Araújo²

DOI 10.5935/2595-0118.20180034

\section{ABSTRACT}

BACKGROUND AND OBJECTIVES: Very little is known about the epidemiology of chronic pain in Brazil; especially in the case of multiple pain prevalence surveys. Knowing about the prevalence of chronic pain in the Brazilian population is an important step in revealing the scope and magnitude of its effects, providing a guide to preventive and intervention strategies, mainly public policies. The objective is to review descriptively the publications made in Brazil to estimate the prevalence of chronic pain in the Brazilian population.

CONTENTS: The search in the indexed database of the Portal of Periodicals of CAPES with the Descriptors in Health Sciences: "Prevalence" and "Chronic Pain" returned, after the screening, a total of 10 articles. The prevalence of chronic pain varied from 29.3 to $73.3 \%$, affecting more women than men and the most prevalent site was the dorsal/lumbar region. Most of the studies showed percentage higher than the estimated for the world population. However, we cannot say that the prevalence of chronic pain in the Brazilian population is higher since the values of the surveys reflect only regional data.

CONCLUSION: The studies found in this review showed a recent interest in the epidemiology of chronic pain in the country, all in the last decade. However, they do not allow an accurate estimate, and more studies are needed to obtain a representative prevalence of the Brazilian population.

Keywords: Chronic Pain, Prevalence, Review.

\footnotetext{
1. Instituto Federal de Educação, Ciência e Tecnologia do Tocantins, Palmas, TO, Brasil 2. Universidade Federal do Tocantins. Palmas, TO, Brasil.

Submitted in August 14, 2017.

Accepted for publication in March 29, 2018.

Conflict of interests: none - Sponsoring sources: none.

Correspondence to:

Quadra 109 Norte, Avenida NS-15, ALCNO-14 - Plano Diretor Norte

77001-090 Palmas, TO, Brasil.

E-mail: holanda.fv@gmail.com

(C) Sociedade Brasileira para o Estudo da Dor
}

\section{RESUMO}

JUSTIFICATIVA E OBJETIVOS: Muito pouco se conhece sobre a epidemiologia da dor crônica no Brasil; principalmente, tratando-se de pesquisas de prevalência de dores múltiplas. Conhecer sobre a prevalência da dor crônica na população brasileira é um passo importante no sentido de revelar a abrangência e magnitude de seus efeitos, proporcionando um direcionamento para as estratégias preventivas e de intervenção, principalmente políticas públicas. O objetivo deste estudo foi revisar descritivamente as publicaçôes realizadas no Brasil para estimar a prevalência de dor crônica na populaçáo brasileira.

CONTEÚDO: A busca se deu na base de dados indexadas do Portal de Periódicos da CAPES com os Descritores em Ciências da Saúde: "Prevalência» e "Dor crônica» retornou, após a triagem, um total de 10 artigos. A prevalência de dor crônica dos trabalhos variou de 29,3 a $73,3 \%$, tendo afetado mais mulheres que homens e o local mais prevalente foi a região dorsal/lombar. A grande parte dos estudos encontrou uma percentagem maior que a estimada na população mundial, no entanto não se pode afirmar que a prevalência de dor crônica da populaçáo brasileira seja de fato maior, uma vez que os valores das pesquisas refletem apenas dados regionais.

CONCLUSÁO: Os estudos encontrados demonstraram um recente interesse sobre a epidemiologia da dor crônica no país, todos da última década; porém, não permitem uma estimativa precisa, sendo necessário mais estudos para se obter uma prevalência representativa da população do Brasil.

Descritores: Dor crônica, Prevalência, Revisão.

\section{INTRODUCTION}

Pain is a multifactorial condition, difficult to understand, defined by the International Association for Study of Pain (IASP) as an "unpleasant sensorial and emotional experience associated to a real injury or described in such terms $s^{1}$. When acute, it has an important biological value in preserving the individual's integrity since it is a symptom that alerts for occurrences of injuries in the body, but the chronic pain does not have this characteristic ${ }^{2}$. Since it causes absenteeism, temporary or permanent disability, morbidity and high costs to the health system, pain has been considered a public health problem ${ }^{3}$.

IASP clarifies that best starting point in the differentiation between chronic and acute pain is three months of its occurrence, but for research purposes, it suggests a period of six months ${ }^{4}$. The prevalence of chronic pain in the world is estimated around 10.1 to $55.5 \%$, with a $35.5 \%$ average ${ }^{5}$. In Brazil, although there are not many epidemiological studies, the 
incidence is similar to that estimated by IASP ${ }^{6}$. In Spain, research by telephone with 5,000 houses found a prevalence of chronic pain of $23.4 \%$ in the general population 7 . In Norway, $24.4 \%$ of 4,000 Norwegians respondents stated that they had chronic pain, and $65 \%$ of them reported the pain experience for over 5 years 8 .

Very little is known about the epidemiology of chronic pain in Brazil, mainly regarding the research on the prevalence of multiple pains. Studies like these that assess pain in several areas of the body are important because they contribute to the identification of susceptibility to pain, they can demonstrate the occurrence of associated pain, allowing a broader view of the phenomenon in the population and providing input to preventive actions plans and organization of the health service'. Studies about the prevalence of specific pain related to the clinic are important to provide new technologies in the management and assessment of pain, but they do not show representativeness of the population for presenting characteristics that make generalization impracticable. Studies with the general population are very valuable. However, it is lack of publications addressing the Brazilian population?.

Knowing the prevalence of chronic pain in the Brazilian population is an important step to unveil the breadth and magnitude of its effect, providing a guide for preventive and intervention strategies, mainly for public policies.

The objective of this study was to carry a descriptive review of publications in Brazil to estimate the prevalence of chronic pain in the Brazilian population.

\section{CONTENTS}

All indexed articles, written in any language, which reported data on the prevalence of chronic pain in the general Brazilian population or its specific classes, such as students, workers, the elderly etc., were included, regardless the concept of chronic pain established in the study, age or gender, the data collection instruments and the date of publication. Duplicate papers published in different journals were excluded.

The search was on the database indexed in the CAPES Journals Portal using the Health Science Keywords (DeCS): "Prevalence" and "chronic pain" in October 2016. The articles were selected based on the reading of the title or abstract. Those potentially eligible were read in full.

The search found a total of 91 articles. Of these, after the screening, 11 studies were included. One article was excluded because it was published in two different journals, totaling a sample of 10 papers $^{9-18}$. The total population of the selected studies was 8,508 individuals, of which the samples ranged from $60^{15}$ to $2,297^{12}$ participants.

The variables of interest were the first author, year of publication, type of study, data collection instrument, sample size, population, age, gender, concept of chronic pain, percentage of prevalence and the most prevalent pain location, that were transferred by one of the authors to the Microsoft spreadsheet (Table 1). It was not possible to perform the meta-analysis due to the heterogeneity of the papers. All data of interest were analyzed using descriptive statistics.

Table 1. The prevalence rate of chronic pain in the Brazilian population

\begin{tabular}{|c|c|c|c|c|c|c|c|c|c|c|}
\hline Authors & $\begin{array}{l}\text { Types of } \\
\text { Studies }\end{array}$ & $\begin{array}{l}\text { Types of } \\
\text { collection }\end{array}$ & $\begin{array}{l}\text { Sample } \\
\text { size (n) }\end{array}$ & Gender & Population & $\begin{array}{c}\text { Average } \\
\text { age } \\
\text { (years) }\end{array}$ & $\begin{array}{l}\text { Concept of } \\
\text { chronic pain }\end{array}$ & $\begin{array}{c}\text { Prevalence } \\
\text { of chronic } \\
\text { pain }\end{array}$ & $\begin{array}{l}\text { Pain site of } \\
\text { the highest } \\
\text { prevalence }\end{array}$ & $\begin{array}{c}\text { Higher } \\
\text { prevalence } \\
\text { between } \\
\text { genders }\end{array}$ \\
\hline $\begin{array}{l}\text { Dellaroza, } \\
\text { Pimenta and } \\
\text { Matsuo }^{10}\end{array}$ & $\begin{array}{l}\text { Cross- } \\
\text { sectional }\end{array}$ & $\begin{array}{c}\text { Home } \\
\text { interview }\end{array}$ & 451 & $\begin{array}{l}64.7 \% \\
\text { Male }\end{array}$ & $\begin{array}{l}\text { Aged civil } \\
\text { servants of } \\
\text { Londrina-PR }\end{array}$ & 68.6 & $\begin{array}{l}\text { Lasting for } \\
6 \text { months or } \\
\text { more }\end{array}$ & $51.4 \%$ & $\begin{array}{c}\text { Back region } \\
21.7 \%\end{array}$ & $\begin{array}{l}31.9 \% \\
\text { Male }\end{array}$ \\
\hline Sá et al..$^{12}$ & $\begin{array}{l}\text { Cross- } \\
\text { sectional }\end{array}$ & $\begin{array}{c}\text { Home } \\
\text { interview }\end{array}$ & 2.297 & $\begin{array}{l}55.5 \% \\
\text { Female }\end{array}$ & $\begin{array}{l}\text { Adults living in } \\
\text { Salvador. BA }\end{array}$ & 40.9 & $\begin{array}{l}\text { More than } 6 \\
\text { months. }\end{array}$ & $41.4 \%$ & $\begin{array}{l}\text { Lumbar } \\
\text { region } \\
16.3 \%\end{array}$ & $\begin{array}{l}48.4 \% \\
\text { Female }\end{array}$ \\
\hline $\begin{array}{l}\text { Vieira et } \\
\text { al. }{ }^{14}\end{array}$ & $\begin{array}{l}\text { Population- } \\
\text { based } \\
\text { cross- } \\
\text { sectional }\end{array}$ & $\begin{array}{c}\text { Home } \\
\text { interview }\end{array}$ & 1.597 & $\begin{array}{l}66.4 \% \\
\text { Female }\end{array}$ & $\begin{array}{l}\text { Adults living in } \\
\text { the city of São } \\
\text { Luís. MA }\end{array}$ & 37.6 & $\begin{array}{l}\text { Lasting for } \\
\text { at least } 6 \\
\text { months. }\end{array}$ & $42.3 \%$ & $\begin{array}{c}\text { Women } \\
\text { - head } \\
40.46 \% \\
\text { Men - } \\
\text { lumbar } \\
39.47 \%\end{array}$ & $\begin{array}{l}45.4 \% \\
\text { Female }\end{array}$ \\
\hline
\end{tabular}


Table 1. The prevalence rate of chronic pain in the Brazilian population - continuation

\begin{tabular}{|c|c|c|c|c|c|c|c|c|c|c|}
\hline Authors & $\begin{array}{l}\text { Types of } \\
\text { Studies }\end{array}$ & $\begin{array}{c}\text { Types of } \\
\text { collection }\end{array}$ & $\begin{array}{l}\text { Sample } \\
\text { size (n) }\end{array}$ & Gender & Population & $\begin{array}{l}\text { Average } \\
\text { age } \\
\text { (years) }\end{array}$ & $\begin{array}{l}\text { Concept of } \\
\text { chronic pain }\end{array}$ & $\begin{array}{l}\text { Prevalence } \\
\text { of chronic } \\
\text { pain }\end{array}$ & $\begin{array}{l}\text { Pain site of } \\
\text { the highest } \\
\text { prevalence }\end{array}$ & $\begin{array}{l}\text { Higher } \\
\text { prevalence } \\
\text { between } \\
\text { genders }\end{array}$ \\
\hline $\begin{array}{l}\text { Reis, Torres } \\
\text { and Reis }{ }^{15}\end{array}$ & $\begin{array}{l}\text { Cross- } \\
\text { sectional }\end{array}$ & Interview & 60 & $\begin{array}{l}50 \% \\
\text { Male }\end{array}$ & $\begin{array}{l}\text { Aged of the } \\
\text { Leur Britto } \\
\text { Foundation - } \\
\text { Jequié. BA }\end{array}$ & 77.6 & Not informed & $73.3 \%$ & $\begin{array}{l}\text { Back } \\
31 \%\end{array}$ & $58.4 \%$ Male \\
\hline $\begin{array}{l}\text { Dellaroza } \\
\text { et al. }{ }^{16}\end{array}$ & $\begin{array}{l}\text { Cross- } \\
\text { sectional }\end{array}$ & $\begin{array}{c}\text { Home } \\
\text { interview }\end{array}$ & 172 & $\begin{array}{l}40.7 \% \\
\text { Female }\end{array}$ & $\begin{array}{l}\text { Aged in the } \\
\text { North region of } \\
\text { Londrina. PR }\end{array}$ & 68.9 & $\begin{array}{l}\text { Lasting for } \\
\text { more than } 6 \\
\text { months. }\end{array}$ & $62.2 \%$ & $\begin{array}{l}\text { Lower limbs } \\
31.4 \%\end{array}$ & $65.4 \%$ Female \\
\hline $\begin{array}{l}\text { Dellaroza } \\
\text { et al. }{ }^{17}\end{array}$ & $\begin{array}{l}\text { Cross- } \\
\text { sectional }\end{array}$ & $\begin{array}{c}\text { Home } \\
\text { interview }\end{array}$ & 1.271 & $\begin{array}{l}59.6 \% \\
\text { Female }\end{array}$ & $\begin{array}{l}\text { Aged living } \\
\text { in São Paulo } \\
\text { participants of } \\
\text { the Health. Well- } \\
\text { being and Aging } \\
\text { (SABE) project }\end{array}$ & 69.5 & $\begin{array}{l}\text { Lasting for } \\
6 \text { months or } \\
\text { more }\end{array}$ & $29.7 \%$ & $\begin{array}{l}\text { Lumbar } \\
\text { region } \\
25.4 \%\end{array}$ & Not informed \\
\hline $\begin{array}{l}\text { dos Santos } \\
\text { et al. }{ }^{18}\end{array}$ & $\begin{array}{l}\text { Cross- } \\
\text { sectional }\end{array}$ & $\begin{array}{c}\text { Home } \\
\text { interview }\end{array}$ & 1.705 & $\begin{array}{l}62.5 \% \\
\text { Female }\end{array}$ & $\begin{array}{l}\text { Aged living in } \\
\text { Florianópolis }\end{array}$ & 70.7 & $\begin{array}{l}\text { Lasting for } \\
\text { six months } \\
\text { or more. of } \\
\text { continuous } \\
\text { character or } \\
\text { recurrent. }\end{array}$ & $29.3 \%$ & Not informed & $\begin{array}{l}62.5 \% \\
\text { Female }\end{array}$ \\
\hline
\end{tabular}

From the eligible studies, it was observed that the prevalence of chronic pain is a recent concern since the publications refer to the 2006-2015 period. The average age of the population in the studies varied between $21.1^{11}$ and 77.6 years ${ }^{15}$. Five of them had conducted exclusively with the senior subjects ${ }^{10,15-18}$, four with adults also including senior people $e^{9,12-14}$ and one with younger individuals, Nursing students ${ }^{11}$. None included children. The fact that all the studies included or had aged subjects in the studied population returned relatively high prevalence values since the occurrence of pain increases with age $\mathrm{e}^{19}$.

The current results show the heterogeneity in the methods, types of studied population and results, preventing any significant data grouping. The preference for classes linked to projects or institutions may have occurred due to the easiness to obtain these samples.

The research method used in all studies was the cross-sectional. The data collection of the majority of the studies was a home interview with the subjects. Only 4 were carried out in institutions ${ }^{9,11,13.15}$. The most interesting result that can be observed in this review is that the prevalence of chronic pain was significant in all studies. The lowest prevalence was in Florianopolis (Santa Catarina) of $29.3 \%{ }^{18}$, and the highest in Jequié (Bahia) of $73.3 \%{ }^{15}$. Although most of the studies ${ }^{9,10-16}$ present a percentage higher than the estimated for the world's population ${ }^{5}$, one cannot say that the prevalence of chronic pain in the Brazilian population is larger, since the values only reflect regional data. A literature review on the prevalence of chronic pain in Holland found a variation of prevalence between 2 and $40 \%$ in the population ${ }^{20}$, divergent from the values found in this paper. In the United Kingdom, $46.5 \%$ of the general population of the country also experience chronic pain ${ }^{21}$.

The definition of chronic pain as an independent variable was not presented in 2 papers ${ }^{13,15}$. In the others, the definition was equivalent to the IASP ${ }^{4}$. The most prevalent site of chronic pain was the lumbar/back region ${ }^{10,12,14,15,17}$, followed by the head ${ }^{9,11,14}$. Only one of the studies informed the site of pain by gender ${ }^{14}$, and one study did not present the site of pain ${ }^{18}$. In a survey conducted with a representative sample in the United States ${ }^{22}$ showed that the most prevalent site of pain was also the back (10.1\%), followed by legs/feet (7.1\%), arms/hands (4.1\%) and head $(3.5 \%)$.

All the studies included men and women. Females had a higher presence in most samples ${ }^{9,12,14,16-18}$. Only in two studies, males prevailed $^{10,13}$. One study failed to present the quantity of the sample distributed by gender ${ }^{11}$, and one of the samples had an equitable representation among peers ${ }^{15}$. Those who had a higher number of men in the sample had a higher prevalence of chronic pain in males and those who had a higher number of women, a higher prevalence in females. Only one of the studies did not present the prevalence by gender ${ }^{17}$. Therefore, the prevalence of the chronic pain in the studies was higher in women than in men. This prevalence in females is also shown in other studies ${ }^{7,8,22-27}$.

\section{CONCLUSION}

The studies found showed recent interest in the epidemiology of chronic pain in the country, all of them in the last decade, but there is still the need for further studies to obtain a representative prevalence in the Brazilian population. It was not possible to state that the prevalence of chronic pain in the Brazilian population is in the interval found in the studies due to the heterogeneity and regionality of the studies.

\section{REFERENCES}

1. Witte W, Stein C. History, Definitions and Contemporary Viewpoins. In: Kopf A, Patel NB, editors. Guide to pain Management in Low-Resource Settings. Seattle; IASP; 2010. 3-8p.

2. Teixeira MJ. Fisiopatologia da nocicepçấo e da supressão da dor. Jornal Brasileiro de Oclusão, ATM e Dor Orofacial. 2001;1(4):329-34.

3. Picavet HS, Schouten JS. Musculoskeletal pain in the Netherlands, prevalences, consequences and risk groups, the DMC(3)-study. Pain. 2003;102(1-2):167-78.

4. Merskey H, Bogduk N. Classification of chronic pain - descriptions of chronic pain syndromes and definitions of pain terms. $2^{\text {nd }}$ ed. Seattle: IASP Press; 1994.

5. Harstall C, Ospina M. How prevalent is chronic pain? Pain: Clinical Updates. 2003;11(2):1-4. 
6. Cipriano A, Almeida DB, Vall J. Perfil do paciente com dor crônica atendido em um ambulatório de dor de uma grande cidade do sul do Brasil. Rev Dor. 2011;12(4):297300 .

7. Català E, Reig E, Artés M, Aliaga L, López JS, Segú JL. Prevalence of pain in the Spanish population: telephone survey in 5000 homes. Eur J Pain. 2002;6(2):133-40.

8. Rustøen T, Wahl AK, Hanestad BR, Lerdal A, Paul S, Miaskowski C. Prevalence and characteristics of chronic pain in the general Norwegian population. Eur J Pain. 2004;8(6):555-65.

9. Krelling MC, da Cruz DA, Pimenta CA. [Prevalence of chronic pain in adult workers]. Rev Bras Enferm. 2006;59(4):509-13. Portuguese.

10. Dellaroza MS, Pimenta CA, Matsuo T. [Prevalence and characterization of chronic pain among the elderly living in the community]. Cad Saude Publica. 2007;23(5):115160. Portuguese.

11. Silva DS, Ferraz CG, Souza LA, Cruz LV, Stival MM, Pereira LV. Prevalência de dor crônica em estudantes universitários de enfermagem. Texto Contexto Enferm. 2011;20(3):519-25.

12. Sá K, Baptista AF, Matos MA, Lessa I. [Prevalence of chronic pain and associated factors in the population of Salvador, Bahia]. Rev Saude Publica. 2009;43(4):622-30. Portuguese.

13. Almeida JG, Kurita GP, Braga PE, Pimenta CA. [Chronic pain in schizophrenic patients: prevalence and characteristics]. Cad Saude Publica. 2010;26(3):591-602. Portuguese.

14. Vieira EB, Garcia JB, Silva AA, Araújo RL, Jansen RC, Bertrand AL. Chronic pain, associated factors, and impact on daily life: are there differences between the sexes? Cad Saude Publica. 2012;28(8):1459-67.

15. Reis LA, Torres Gde V, Reis LA. Pain characterization in institutionalized elderly patients. Arq Neuropsiquiatr. 2008;66(2-B):331-5.

16. Dellaroza MS, Furuya RK, Cabrera MA, Matsuo T, Trelha C, Yamada KN, et al.
[Characterization of chronic pain and analgesic approaches among community-dwelling elderly]. Rev Assoc Med Bras. 2008;54(1):36-41. Portuguese.

17. Dellaroza MS, Pimenta CA, Duarte YA, Lebrăo ML. [Chronic pain among elderly residents in São Paulo: prevalence, characteristics, and association with functional capacity and mobility (SABE Study). Cad Saude Publica. 2013;29(2):325-34. Portuguese.

18. dos Santos FA, de Souza JB, Antes DL, d'Orsi E. Prevalence of chronic pain and its Association with the sociodemographic situation and physical activity in leisure of elderly in Florianópolis, Santa Catarina: population-based study. Rev Bras Epidemiol. 2015;18(1):234-47. English, Portuguese.

19. Eriksen J, Jensen MK, Sjogren P, Ekholm O, Rasmussen NK. Epidemiology of chronic non-malignant pain in Denmark. Pain. 2003;106(3):221-8.

20. Verhaaka PF, Kerssensa JJ, Dekkera J, Sorbib MJ, Bensinga JM. Prevalence of chronic benign pain disorder among adults: a review of the literature. Pain. 1998;77(3):231-9.

21. Elliott AM, Smith BH, Penny KI, Smith WC, Chambers WA. The epidemiology of chronic pain in the community. Lancet. 1999;354(9186):1248-52.

22. Hardt J, Jacobsen C, Goldberg J, Nickel R, Buchwald D. Prevalence of chronic pain in a representative sample in the United States. Pain Med. 2008;9(7):803-11.

23. Crook J, Rideout E, Browne G. The prevalence of pain complaints in a general population. Pain. 1984;18(3):299-314

24. Buskila D, Abramov G, Biton A, Neumann L. The prevalence of pain complaints in a general population in Israel and its implications for utilization of health services. J Rheumatol. 2000;27(6):1521-5.

25. Montini FT, Neman FA. Prevalência e avaliação da dor crônica nos cadastrados da unidade básica de saúde Jardim Palmira, Guarulhos/SP. Science in Health. 2012;3(2):74-86

26. Ruviaro LF, Filippin LI. Prevalência de dor crônica em uma Unidade Básica de Saúde de cidade de médio porte. Rev Dor. 2012;13(2):128-31

27. Leite F, Gomes JO. Dor crônica em um ambulatório universitário de fisioterapia. Rev Ciênc Méd. 2006;15(3):211-21. 